DOI: $10.1515 /$ hssr -2015-0007

\title{
The Word - an Extensive Topography
}

Adrian Lucian Dinu*,

"Alexandru Ioan Cuza" University of Iaşi, Romania

Claudia Elena Dinu**

"Grigore T. Popa" University of Medicine and Pharmacy of Iaşi, Romania

\begin{abstract}
This article intends to analyse crossings between words and the Word. To this purpose, we will present linguistic and spiritual connotations of the terms belonging to the semantic field of the verb "to communicate" and of the idea of communication. We will also deepen the pneumatologic curative issue of the Word. The final section of the article will draw on the description of the extensive references in the relation between words and the Word.
\end{abstract}

Keywords

Logos, Spirituality, Linguistics, Pneumatology, Culture.

\section{Introduction}

The Word is one of the realities that confers man his dignity of a rational and spiritual being. Rev. Prof. Dumitru Stăniloae (1903-1993) argued that: "Christianity consists of communication and the reception of the divine word: in Jesus Christ Himself we have only divine "word", meaning speech addressed to the people"1. We reach the essence when we notice that, first of all, faith

\footnotetext{
*Faculty of Orthodox Theology, "Alexandru Ioan Cuza" University of Iaşi, 11, Carol I Blvd., 700506; pradriandinu@yahoo.com

** Faculty of Medicine, "Grigore T. Popa" University of Medicine and Pharmacy of Iaşi, 16, University st., 700115; claudiaelena.dinu@yahoo.com
} 
is supported by the possibility of a dialogue between man and God. Prayer itself is no longer mere communication, an address among all others, but a deed of man and a divine gift. As a dialogic being, as he has been called, man found his Inter-locutor - God - with Whom he relates in a privileged relationship, and through prayer he ascends to Christian completeness. In Romanian, "a comunica" (to communicate) is a neologism from French. The result of the diachronic evolution of the language has privileged an "ecclesiastic" meaning, while the Latin communicare generated the Romanian cuminecare (communion). A complex communicational model illustrates the horizontal communication between people, meaning society in its constructed and controlled structures, as well as the one coming from the sense of cuminecare (communion), which leads to a "verticalization" of the communicational relationship. In Christian literature, the Word has also the meaning of divine Word, of Logos. Thus, in Romanian, the metaphysical, spiritual sense has been kept, which warrants and justifies an exegesis of this type of communicational processes ${ }^{2}$.

\section{Word and communication - the elements of spiritual linguistics}

Spiritual communication is tightly connected to the Word. In the beginning was the Word, and the Word was with God, and the Word was God (John 1:1). Somewhere else in the Holy Scripture it is mentioned: "Heaven and earth will pass away, but My words will never pass away" (Mathew 24:35).

The Church is perhaps the one that best understood the sense of communication and of words, which is why the first Christians spoke little, but always in essence, taking everything in a formative and spiritual way.

Communication in Church means first of all prayer, or address that is holy, blessing, and beneficial to the being. And in prayer, there are words, gestures, movements of the soul and of the body, a complete communicative involvement of man. The word finds its true power in prayer, because here the word is a mutual communion between God and man. Therefore, the word is a reality, a deep reality implying the passage from its level of information to the level of communion, of experience. The double aspect of the Word as received by men is revealed by St. 
Paul the Apostle (born approx. in year 5 in Tarsus - Cilicia, passed away in year 67, Rome), who wrote: "And we also thank God continually because, when you received the word of God, which you heard from us, you accepted it not as a buman word, but as it actually is, the word of God, which is indeed at work in you who believe." (1 Thessalonians 2:13).

Another Father from ancient times - St. Gregory of Sinai (12551346) speaks about the word and its qualities: "The word derived from teachings varies in accordance with the diverse ways in which it is put together from different sources. These sources are four in number: instruction, reading, ascetic practice, and grace. For just as water, while essentially the same, changes and acquires a distinctive quality according to the composition of the soil under it, so that it tastes bitter, or sweet, or brackish, or acidic, so does oral teaching, coloured as it is by the moral state of the teacher, vary accordingly in the way it operates and in the benefits it confers" 3 .

The word that is socially spread nowadays is based on informational content: newspapers, TV channels, the Internet include information in their manner of making words work. However, when two people tell each other: "I love you", this is no longer mere information; they commune with each other, they mutually eternalize through love, and this exists and is vertically supported, as God Himself is Love. This is the spiritual plan of the word ${ }^{4}$.

"Prayer is the sacrament of the union of man with God", Rev. Professor Dumitru Stăniloae wrote. This results in the paradox of the mystical aspect of communication (in fact, of comuniune (togetherness) and

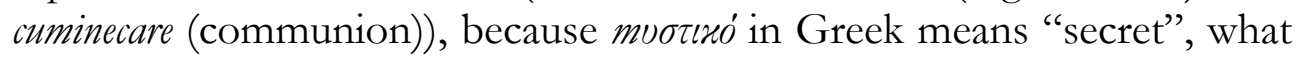
should not be said. We find in father Stăniloae's work a deepening of the spiritual communicative valences of the word, in a dichotomous approach referring to spirituality and the linguistic perspective on the word as an element of communication: "...persons and things as well as words become our paths towards the sacrament of God's connection to us, and at the same time paths of our spiritual ascent to Him. In prayer, the word bears in itself more than what can be determined in the analysis of the inner mechanisms of the language (e.g. significance/significant, denotation/connotation). Words embody meanings oriented towards the understanding of the sacrament of God's connection to men, meanings that carry man towards God, meanings that presentiate the divine power by supporting this way of communication"'5. The formative meaning of the 
Word that is decisive in the fulfilment of man's vocation is also emphasized here.

Therefore, spiritual communication is communion and togetherness, a reality that establishes the relation conferring substantiality to faith and its manifestation as an experience by way of vocatus. Its fundamental condition is: if God is a You, He can awaken and build humanly and spiritually a "You" in "I" and in "he"/"she" (in any fellow human being). In prayer, the believer longs to the shore, to what fulfils him as a man, but at the same time prayer is the shore to which he longs. Through prayer, God is blessed and praised, but by prayer he who blesses and praises God is blessed and praised by God, as well. In suggestive wording: the soul of the man who prays is like a plant thirsty for water, meaning thirsty for God, but at the same time it is full of divine sap 6 .

The first Christians best understood the mission of the Word, preaching God's Word even by being silent. Their wisdom came from the life-streaming words of the Bible and from the words of the prayers to God. Father Rafail Noica, son of the great Romanian philosopher Constantin Noica, identifies the role of the words that are a spiritual source and resource: "Let us pay attention [...] to the word of the Bible, to the word of the prayer, because it hides the spring of life. It is hidden, but it reveals itself as we want to learn. The Word is one of God's names. He is called the Son, but He is also the Word and God, which is why the Word [...] has metaphysical roots, it is not merely "random noise" through which I can say something and you can understand my reason. The Word comes from divine energies. Through word, God made heaven and earth. God said "let there be" and "there was".

Hence, what remains essential in Church and from the theological point of view on reality is the communication-communion models: the Holy Liturgy, the morning and evening prayers, the Sacraments and lifeblessing services, which are all full-filling for man here on earth and in eternal life, meaning that together they build the fullness and plenitude of human beings. The Romanian language proves extraordinary again due to the coagulation of meanings, due to the semantic reunion that suggests a kind of transcension of the diachrony and of the phenomena apparently diverging from linguistic evolution. 
Adrian Lucian Dinu, Claudia Elena Dinu, The Word - an Extensive Topography

HSS, vol. IV, no. 1 (2015): 111-118

\section{The Word - curative pneumatologic nutriment}

The prayer or the word of God is a purifying, sanctifying, refreshing energy, and through these energies we enter the Energy of God as a Creator. "It is absolutely necessary for us to overcome the informative level of the word and reach the level of communion, of prayer, according to the teaching of the Holy Scriptures, in our communication with one another, because it is then when we achieve communion - Holy Communion - maybe not yet with Christ's Flesh and Blood, but with Christ, God's Word. The Holy Liturgy is also conceived so as to culminate first with the communion of the word and afterwards, the second part of the Liturgy culminates with Christ's Flesh and Blood. The Holy Liturgy reminds us also of the Last Supper when, before the Lord offered the Eucharist to his Apostles, He told them that they were purified by the words He had told them" 8 .

When speaking about the word and its power to build, to form and deform people, researchers of the phenomena under discussion certify that the word is energy that creates and that creates individuals, that embodies the human being. The word is awareness and a product of the will to communicate, having two aspects: a poetic aspect and a dynamic aspect. "When the subjects of communication are at the same ontological level, the possibilities of understanding and enriching each other depend on the language".

The Word is a freely consented self-manifestation of God and a kenosis at communicational level. By means of the word, life realities become obvious, but the most important fact is that - without diminishing or limiting itself, the word conveys energy or power to the people around. And again, this is a personal form of manifestation of every man's personality. People and even modern technology use the uttered or written word so that every man and the world in general could be called to higher realities, and the Church, by way of maternal pedagogy, calls us to communion and meaningful life by means of the word. What is important is the fact that spiritual and biblical aspects are often explained in the church based on data or phenomena related to the natural world, as Isaiah ( $7^{\text {th }}$ century B.C.) - one of the four great prophets of the Old Testament together with Jeremiah, Ezekiel and Daniel - says: "For as the rain and the snow come down from beaven and do not return there but water the earth, making it bring forth and sprout, giving seed to the sower and bread to the eater, so shall my word be that goes out from my mouth; it shall not return to me empty, but it shall accomplish that which I purpose, and shall succeed in the thing for which I sent it." (Isaiah 55:10-11). 


\section{Conclusion}

There is a continuum of the sacramental cycle that springs from Church and influences society. The sanctifying power of God's Word calls each human being to communion and eternal joy. The world and its realities penetrated by spirituality are a "deaconry" of the communication calling to communion.

Through its theandric being itself, the Church cannot disregard the human element, the cultural dimension of the word, just as it cannot fail to acknowledge divine Revelation and the divine grace from the Logos. Christ the Saviour spoke the language of the people among whom He came. He knew the people's traditions and habits as well as their daily concerns and, through an intra-topical and intra-logical position, $\mathrm{He}$ spoke to the soul depths and opened them extra-topically and extralogically. "Christians do not differ from the rest of the world by the earth they live on, or their language, or clothing. [...] They are in a body, but do not live for their body. They live on earth, but they are inhabitants of heaven. They go by the state laws, but they defeat laws in their way of living"10.

For two millennia, the Church has dialogued with different languages and cultures, and due to these relations, the language of the Church for the communication of belief permanently deepens. Raising through the work of the Spirit, the dough of the divine Word is baked as a bread of cultures and civilizations. Pneumato-Logy feeds in a prolific and redeeming way the Ethno-logy, because God's Spirit continues to travel above waters.

\section{References}

*, Epistola către Diognet, ch. 5, in: „Scrierile Părinților Apostolici”, translation, indeces and notes by Priest Dumitru Fecioru, (PSB no. 1). Bucharest : EIBMBOR Publishing House, 1979.

Dinu, Mihai, Comunicarea. București : Editura Ştiințifică, 1999.

Dumitrescu, Sorin, 7 dimineți cu părintele Stăniloae. Convorbiri realizate de Sorin Dumitrescu. București : Editura Anastasia, 1992.

Noica, Ierom. Rafail, Celalalt Noica - mărturii ale monabului Rafail, insoțite de câteva cuvinte de folos ale părintelui Symeon. București: Editura Partener, 2004.

Petraru, Priest Gheorghe, Misiologie Ortodoxă. Iași : Panfilius Publishing House, 2002.

St. Gregory of Sinai, Capete in acrostih, in: „Filocalia sfintelor nevoințe ale 
desăvârşirii sau culegere din scrierile Sfinților Părinți care arată cum se poate omul curăţa, lumina şi desăvârşi”, translation from Greek, introduction and notes by Priest Prof. DumitruStăniloae, PhD., vol. 7, Bucharest : EIBMBOR Publishing House, 1977.

Stăniloae, Dumitru, Iisus Hristos sau restaurarea omului. Craiova : Omniscop Publishing House, 1993.

Idem, Ortodoxie şi românism, in: „Trăirea lui Dumnezeu în Ortodoxie”. ClujNapoca : Editura Dacia, 1993.

Idem, Spiritualitate și comuniune in Liturghia ortodoxă. Bucharest : EIBMBOR Publishing House, 2004.

${ }^{1}$ Rev. Prof. Dumitru Stăniloae, PhD., Ortodoxie și românism, in: „Trăirea lui Dumnezeu în Ortodoxie" (1993). Cluj-Napoca : Editura Dacia. 113.

${ }^{2}$ Mihai Dinu, Comunicarea (1999). București: Editura Ştiinţifică. 13.

${ }^{3}$ St. Gregory of Sinai, Capete in acrostih, in: „Filocalia sfintelor nevoințe ale desăvârşirii sau culegere din scrierile Sfinţilor Părinţi care arată cum se poate omul curăţa, lumina şi desăvârrşi” (1977), translation from Greek, introduction and notes by Rev. Prof. Dumitru Stăniloae, PhD., vol. 7, Bucharest : EIBMBOR Publishing House. 122-123.

${ }^{4}$ Rev. Prof. Dumitru Stăniloae, Spiritualitate şi comuniune in Liturghia ortodoxă (2004). Bucharest : EIBMBOR Publishing House. 16-17.

${ }^{5}$ Dumitru Stăniloae, Iisus Hristos san restaurarea omului (1993). Craiova : Omniscop Publishing House. 31.

${ }^{6}$ Sorin Dumitrescu, 7 dimineţi cu părintele Stăniloae. Convorbiri realizate de Sorin Dumitrescu (1992). București : Editura Anastasia. 86.

${ }^{7}$ Rafail Noica, Celalalt Noica - mărturii ale monahului Rafail, insoțite de câteva cuvinte de folos ale părintelui Symeon (2004). București: Editura Partener.65.

${ }^{8}$ Ibidem.

${ }^{9}$ Rev. Petraru Gheorghe, Misiologie Ortodoxă (2002). Iași : Panfilius Publishing House. 99.

10 Epistola către Diognet, ch. 5, in: „Scrierile Părinților Apostolici” (1979), translation, indeces and notes by Rev. Dumitru Fecioru, (PSB no. 1). Bucharest: EIBMBOR Publishing House. 339-340. 


\section{Biographical notes}

Rev. Lecturer Adrian Lucian Dinu, PhD. is affiliated with the Faculty of Orthodox Theology in "Alexandru Ioan Cuza" University of Iaşi. He is an alumnus of this university, holds a $\mathrm{PhD}$ from the University of Bucharest and he attended postgraduate courses at the Higher Education Institute of Chambesy, Switzerland. He has authored five books and numerous articles and studies. He has participated in teaching internships abroad, in the University of Geneva, the University of Fribourg, the University of Lausanne, and the University of Strasbourg.

Lecturer Claudia Elena Dinu, PhD. is affiliated with the Faculty of Medicine, Department of Preventive Medicine and Interdisciplinarity of "Grigore T. Popa" University of Medicine and Pharmacy of Iaşi. She is an alumna of the Faculty of Letters, "Alexandru Ioan Cuza" University of Iaşi, holds a $\mathrm{PhD}$ from the same university, conducted under joint supervision from the University of Freiburg, Germany, and she was awarded a Master's Degree by the University of Geneva, Switzerland. She has published translations, and has authored two books and research articles in Romania and abroad. 